\title{
THE PRESENCE OF THE MINISTRY OF NATIONAL DEFENSE IN THE SOCIAL MEDIA SPACE. ANALYSIS OF THE OFFICIAL COMMUNICATION EFFORT BETWEEN THE YEARS 2012-2017
}

\author{
Rădut BÎLBÎIE \\ “Nicolae Bălcescu” Land Forces Academy, Sibiu, Romania \\ bilbiie@yahoo.com
}

\begin{abstract}
The study presents the emergence and evolution of the Public Relations accounts and products associated with social media platforms, at the official level in the Romanian army. We present the main regulations, the planning and execution structures, the significant moments in the development of the platforms, the successes and errors of the implementation team, the main results obtained by the quantitative and qualitative analysis of the products between the year 2012, the year of implementation. and the present time.
\end{abstract}

Keywords: The Ministry of National Defense, The Directorate for Information and Public Relations (DIRP), Facebook, Twitter, You Tube

\section{A historical perspective}

In the year 2012, the Information and Public Relations structure of the Ministry of National Defense (MND) [1] was a fully professional institution with highly qualified staff, with complex attributions and roles both internally and externally, with strategic vision and annual planning and own ethical standards. [2]

The structure consisted of 35 PR practitioners, military and civilians, graduates from specialized higher education and specializations in the USA, Germany, Switzerland, with professional experience of up to 20 years, who had had 5 to 6 PR positions, ranging from media relations specialist, event organizer, internal communication, planning and analysis, internet and electronic publications, and so on.

There were numerous consolidated public online information tools such as the official Internet sites of the Ministry and the subordinated structures that ensured public information through the network of the web sites of the structures of the Ministry of National Defense, in order to increase the visibility of the activities of the Romanian Armed Forces; their main mission is to contribute to informing national and international audiences. [3] These are supplemented by the electronic publication "MND. Online", managed by the Information and Public Relations Directorate.

It should be mentioned that the Ministry of National Defense is the first public institution in Romania, at the level of the ministries, which initiated in 1996 its own website, as well as the first, of a ministry of defense in Eastern Europe. To this it has been added the sites of media, culture, academia and health institutions, general staffs of the force categories and large units. Because DIRP was in charge with the Press Trust of the Ministry of National Defense, 
with its audiovisual component, the Armata $T V$ portal was opened, a replica of the Youtube platform, hosting documentary films and reportages made by the television and cinema structures under its subordination.

In the years after the emergence of the web 2.0, Hi5, Facebook, Twitter, Youtube platforms, several Romanian cultural institutions, including the National Military Library [4], aware of the opportunities offered by Social Media, opened official pages, posting information about events and actions taken.

The first initiatives of the DIRP aimed at creating a Youtube page in 2009 to exploit the multitude of the audiovisual production of the MND. Alongside the Ministry of Foreign Affairs, the Defense became the second Romanian institution to use such a web 2.0 platform. The effort in this direction stopped after 2010, at the level of the MND management there was no wish for the initiation of Facebook or Twitter accounts. As the USA Department of Defense, NATO and many defense ministries in Europe had taken measures to ensure a consistent presence in the social media space, Romanian initiatives were tolerated by the DIRP without being encouraged or established an action policy in the field. The phenomenon can be explained by the fact that the Defense Minister at that time, facing a major crisis of communication with the military reservists, did not want any of the use of all platforms for feedback, obviously a negative feedback for the military organization and his political image. Several personal pages of some known communicators of the MND have been deleted or abandoned, notoriously being the case of the personal page of the DIRP Chief, Admiral Tiberiu Frăţilă. [5]

The social media landscape in Romania in 2010-2012 [6] started to consolidate; it was clearly prefigured what became an undeniable reality in 2012: Facebook will dominate the landscape, dethroning the popular Hi5. [7]

The change of the government in April [8], following a censure motion, brought Corneliu Dobriţoiu, a retired general, [9] as minister of defense, who, having a good knowledge of the organization, of international openness and a positive personal image, de-bureaucratized the decision-making and allowed the strategic reorganization of communication policies towards the new social media platforms, public diplomacy actions, greater social interaction of the armed forces with the civil society.

\section{The emergence of communication tools on the social media platforms of the MND. Guidelines, guides, and policies on Social media. Structure evolution, endowments, actions}

The establishment of the MND official accounts was announced since May, when the head of the DIRP indicated that the institution's priorities were the development of the procedures for the use of Facebook, Twitter, Youtube social media networks [10], as well as the creation of a new media structure in this scope. [11]

Thus, together with the specialists in the Department of Counter-Information and Military Security, procedural aspects were identified to limit vulnerabilities and security incidents, materialized in September 2012 in the Best Practices Guide to Online Socialization. This specialists' dialogue continued with the task of solving some technical and technological issues related to operating, information protection, antivirus, the necessary software and hardware resources. [12]

Public relations specialists from the central, cultural and sports education institutions, from the large units were informed about the procedural aspects related to the setting up and managing of the pages of the respective institutions from the social media platforms. During one day the theoretical, procedural and practical aspects of the field 
were discussed, aiming to familiarize the staff with the new media. [13] Such actions took place later on, each year, involving the public relations staff of the MND institutions.

By order of the Chief of DIRP, in September 2012, a temporary structure was established in the Internal Communication Department, until the modification of the Functional State of the institution, with attributions in the field of Social Media, on the structure of the Documentation Office. In 2016, the office will be named Online Communication.

At the yearly evaluation of the DIRP [14], the Internal Communication Department communicated as achievements of 2012 the realization and updating of the new website and the opening in August 2012 of the MND official accounts on the Facebook and Twitter social networks as well as the elaboration of the previous guide quote.

On December 7, 2012, through the M.148 Order, the Minister of National Defense approved the Instructions on information and public relations activities in the Ministry of National Defense, which confirmed the existence of the specialized structure in the field and the related policies. The Directorate for Information and Public Relations had the following main tasks: to develop and update the Intraman and Internet sites of the Ministry of National Defense, as well as the accounts at the central level of the institution on the YouTube, Facebook and Twitter social networks. [15]

The document further stipulated that, in order to amplify and extend the decentralized communication of the messages of the Ministry of National Defense through communication channels, the Public Information and Public Relations Directorate at the central level of the institution and the other military structures may establish and manage official social network accounts of military institution and military structures concerned. The setting up of social network accounts for the other military structures the armed forces' categories, the headquarters, the educational and cultural institutions - is made with the endorsement of the Public Information and Public Relations Department, which analyzes the opportunity of setting up and management. The information to be published on the social network accounts is endorsed by the structures responsible for the protection of classified information and is approved by the Head of the Public Information and Relations Department or the heads / commanders of the military structures who are responsible for their accuracy and correctness.

The Public Information and Public Relations Directorate is the structure within the military institution which represents, at the central level, the official point of view of the Ministry of National Defense on social networks and the other military structures that open accounts on these networks present the point of view of the respective structure; the individual accounts of the personnel of the Ministry of National Defense, opened in their own name, do not represent the point of view of the military institution. The management of public information posted on the social network accounts of the Ministry of National Defense is regulated by the specifications developed by the Directorate for Information and Public Relations and other structures with attributions in the field [16]. These specifications will be retained and extended by Order M76 / 2016 for the approval of the Instructions on information and public relations activities in the Ministry of National Defense. [17]

Thus, commanders / chiefs of structures will approve the use of social networks or restrict access to them within the premises of military units and issue specifications / orders in this regard. The personnel's access to the personal accounts through the communication and information systems of the MND is accomplished in compliance with the orders and regulations related to 
the organization and conduct of the information and public relations activity and the protection of the classified information. The Military Unit's Public Information and Public Relations Officer, or the legal substitute, appointed or through a pool of duties, manages the official site / pages of the military unit in the social networks after the specialized training provided by the Information and Public Relations Department.

If necessary other persons may post on military units' pages with the approval of the commander of the military unit, after being trained by the personnel responsible for information and public relations or the protection of classified information. Following an impact analysis, with the advice of the Public Information and Public Relations Directorate, other social networks than initially selected can be used to communicate online. Posting the information on the official pages of the MND / military structures in the social networks is carried out according to the following algorithm: a) identification of the specific audience for which the information is intended; b) choosing the appropriate social networking; c) checking materials, information, photographs, films before being posted; d) the endorsement of the security structure for non-public information; e) approval of the commander / chief of the structure; f) posting. [18]

\section{Evolution of the presence in the virtual public space on the social media platforms of the MND}

The benefits of using Social Media platforms are multiple: access to a broad audience, other than the traditional one, minimum costs, interaction with the public, a real source of information for the media, broad spectrum accessibility of a civil public, as well as military, their families, former soldiers now in reserve or retreat. The Ministry of National Defense originally created official pages on social networks Facebook, Twitter and You Tube, responding in this way to the communication needs and the transmission of information to the public of the institution. Subsequently, in 2017, online communication was extended to INSTAGRAM. At this moment the MND has 87 official accounts in the Facebook network, and the Facebook page of the ministry is one of the most active and well maintained institutional pages in Romania. [19]

\begin{tabular}{|l|l|l|l|l|l|l|}
\hline Tools & $\begin{array}{l}\text { Measurable } \\
\text { elements }\end{array}$ & $\mathbf{2 0 1 3}$ & $\mathbf{2 0 1 4}$ & $\mathbf{2 0 1 5}$ & $\mathbf{2 0 1 6}$ & $\mathbf{2 0 1 7}$ \\
\hline \multirow{5}{*}{ Twitter } & $\begin{array}{l}\text { No. of } \\
\text { followers }\end{array}$ & - & 212 & 743 & 1326 & 1945 \\
\cline { 2 - 7 } & $\begin{array}{l}\text { No. of } \\
\text { tweets }\end{array}$ & 105 & 218 & 106 & 162 & 207 \\
\hline \multirow{2}{*}{ Facebook } & $\begin{array}{l}\text { Total no. of } \\
\text { likes }\end{array}$ & 15.898 & 69.193 & 68.660 & 119.172 & 65.329 \\
\cline { 2 - 7 } & $\begin{array}{l}\text { No. of } \\
\text { events }\end{array}$ & 30 & 7 & 9 & 11 & 9 \\
\cline { 2 - 7 } & $\begin{array}{l}\text { Total no. of } \\
\text { posts }\end{array}$ & 1818 & 1806 & 1676 & 2844 & 2467 \\
\cline { 2 - 7 } & $\begin{array}{l}\text { No. of video } \\
\text { posts }\end{array}$ & 92 & 180 & 197 & 647 & 889 \\
\cline { 2 - 7 } & $\begin{array}{l}\text { No. of photo } \\
\text { posts }\end{array}$ & 1726 & 1626 & 1478 & 2197 & 1578 \\
\hline
\end{tabular}




\begin{tabular}{|c|c|c|c|c|c|c|}
\hline \multirow{3}{*}{ Youtube } & $\begin{array}{l}\text { Total no. of } \\
\text { subscriptions }\end{array}$ & - & 1424 & - & 3382 & 4228 \\
\hline & $\begin{array}{l}\text { Total no. of } \\
\text { video } \\
\text { materials }\end{array}$ & 30 & 10 & 7 & 0 & 4 \\
\hline & $\begin{array}{l}\text { Total no. of } \\
\text { views }\end{array}$ & - & 1.374 .932 & 25.406 & 2.205 .064 & 2.495 .826 \\
\hline
\end{tabular}

Figure 1: Quantitative analysis of Facebook, Twitter and Youtube pages of MND

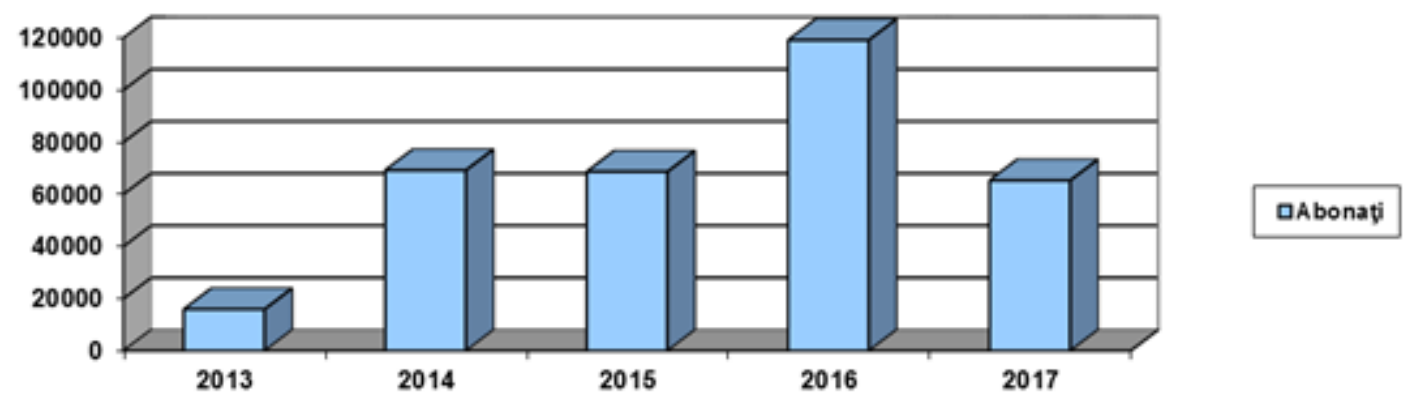

Figure 2: Evolution of the official Facebook page of the MND

Starting from the MND's communication objectives, taking into account the feedback from the page audience, studying Facebook statistics and internal analyzes, the army specialists developed a communication strategy via Facebook, following the indicators: domains of activity (themes and topics) content types (text, photo, audiovideo), frequency of posts (by hours and days of the week). An essential rule is the transmission of information in real time, thus, an information retrieval and posting network has been developed. The MND also plans and carries out periodically in the public space, events through which we promote the pages of the social network institution

To attract target audiences to the page, the Online Communication Bureau initiated or participated in the coverage of a series of special events that were promoted on the MND pages in social networks such as Armata - o şcoală altfel, Ziua Armatei României în şcoli, Militar pentru o zi, Cadet pentru o zi, Mândru de părinții mei,
Fii tu Eroul din poveste, Un Erou o floare. [20]

Treating the events involved a communication plan for each event. Among the social networking posts made to mark the National Day in December 2016 had a significant impact such as:

- Live broadcasts: Front Magazine for the Military Parade: 269203impact, promotion testimonies Military Parade: 755880 impact, two training sessions held in Ghencea: 1475994impact, two training sessions at the Arch of Triumph: average 1.150.354 impact / training, roundup and displacement of the technique and the staff to the Arch of Triumph 435763 impact, the Military Parade at the Arch of Triumph: $1,879,976$ impact, the movement of staff and equipment to the barracks and the interaction with the citizens at the Lujerului Passage: 298058impact, the festive dinner held at the 30 Guard Brigade with the military and guests from Military Traditions Association: 621126impact. 
- Historical posts: Significance of the Day of 1 December 215045impact, Quotes about the meaning of the day 127207impact, Inscriptions on the Arch of Triumph 375044impact,

- Patriotic songs: Marşul lui Iancu, 487761impact, Dac-am plecat Ardealule din tine: 147823impact, Cântă cucu-n Bucovina: 392219impact, Doamne ocroteşte-i pe români 371100impact, Treceţi Batalioane Române Carpaţii197529impact.

- Photographs and photo albums: front magazine, training, preparation of the parade, backstage, interaction with the public at events: $1,084,561$ impact, photos from the country activities167324impact, photos from Afghanistan in the event198544impact.

- Videos: Messages from NATO Commands: 484161impact, Messages from Afghanistan515061impact, Promotional materials by ProPatria2.213.784 impact [21].

\section{Conclusions}

At present social media has become an important part of the public relations. It is common that well-established public relations structures with communication and public relations departments that understand the relevance of their involvement in their institutional work and have integrated into the communication strategy an area for social media activity such as those of the Ministry of National Defense, Foreign Affairs and the Ministry of Interior to represent an example of modern multi-channel communication in Romania.

Social media communication at the ministerial institutional level in Romania is synchronized with the work of other modern societies, as it manifests itself in the same tendencies. Facebook, Twitter and Youtube are the channels most commonly used by other international governmental institutions and are also used by the ministries mentioned.

The Ministry of National Defense manages communication efficiently and professionally through the social media platforms, and by adding new platforms, it proves to be aware of the movement of the public interest towards certain types of domains and be present where the audience they are targeting is present.

\section{References}

[1] The Information and Public Relations Department was established on October 30, 1993 by merging the Information and Public Relations Section and the Press Section of the Ministry of National Defense.

[2] The professionalization process involved also the normalization of the specialized actions, so on May 22, 1995, the first public relations regulation in a governmental structure in Romania, the Instructions on the organization of the information and public relations activity in the Army, followed by a massive methodological guide for application and, later, clarification on how to manage crises. Until now, the above-mentioned instructions have seen seven revisions and changes dictated by the evolution of the DP process, Army transformation, new technologies, NATO entry.

[3] Order no. 148/2012 for the approval of the Instructions regarding the activity of information and public relations in the Ministry of National Defense stipulated in art. 79. - The network of web sites of the structures of the Ministry of National Defense consists of: a) the site www.mapn.ro - a central site, which functions as a master-website and virtual press center of the Ministry of National Defense; is being developed, administered and updated by the Information and Public Relations Directorate; b) A-type websites, created at the level of the departments, the General Staff, the major states of the armed 
forces, Command and the National Defense University "Carol I"; c) B-type websites created at the level of the military structures subordinated to the departments, armed forces categories, Commands, as well as those belonging to the Press Trust of the Ministry of National Defense, military publications, military education, culture, sports or with areas of unique activity in the Ministry of National Defense or those made on occasion of special events.

[4] The National Military Library's website was established in early September 2011, the first post being September 6th. The first event is immortalized on 25 October 2011, awarding the honorary diploma of ARIP prof. Dr. Dumitru Micu at the ceremony organized by ARIP Bucharest Muntenia Branch, the National Military Library and the Society of Military Writers at the end of 80 years of life https://www.facebook.com/bibliotecamilitaranationala/photos/ms.c.eJwtycEJACAMA8C NpE1iSfZfTESfxwGltKkxWV64ttBU2PMdaIydPId1H ;ABmFoMyw - .bps.a.220491808016644.54532.197171093682049/220491834683308/?type $=3 \&$ theater, retrieved March12, 2018, at 13.22.

[5] The first post on Admiral Frăţilă's personal page was only on 31 July 2012 after a break of more than nine months https://www.facebook.com/tiberiu.fratila, retrieved March12, 2018 , at 15.52 .

[6] http://www.manafu.ro/2010/11/social-media-in-romania-noiembrie-2010/, retrieved 12.03.2018, ora 14,27.. Thus, towards the end of 2010, the Romanian social media landscape was dominated by Hi5, which in October had 4,256,944 unique visitors, followed by Trilulilu.ro with 2,795,934 unique visitors, 3rd place was Facebook with 1,866,580 user accounts and 3,800,000 Unique Visitors, followed by TPU.ro with 1,535,334 unique visitors, then Netlog with 921,467 Unique Visitors and Neogen with 884,369 Visitors. At the end of the list are LinkedIn (318,168 accounts), blogging (59,000 Romanian blogs) and finally Twitter with 36,700 user accounts and 700,000 unique visitors. http://www.manafu.ro/2011/12/social-media-in-romania-decembrie2011/, accessed 12.03.2018, 14.28. According to Cristian Manafu's December 2011 statistics, the top three social media platforms that were the most successful in terms of the number of users were: Facebook (5,600,000 Unique Visitors), Hi5 (1,628,825 Unique Visitors) and Trilulilu (2,669,967 unique visitors). Google + had 27,488 users, followed by NETLOG with 818,412 unique visitors. The last three places in the ranking are LinkedIn, Twitter and Blogs. While LinkedIn had 570,146 user accounts and 520,000 unique users, Twitter only had 51,000 user accounts, but more unique users in the number of 570,000 .

[7] http://www.manafu.ro/2012/08/social-media-in-romania-august-2012/, retrieved March12, 2018,at 14.41 Facebook has maintained its top position with 4,953,980 user accounts and $5,600,000$ unique visitors. Pinterest was the second time to have 110,000 unique visitors. Trilulilu is on the third place with 2.085.899 unique viewers. TPU.ro had 2,048,534 unique visitors and 462,679 user accounts. Netlog had 350,000 unique users. LinkedIn has 520,000 unique users, and Twitter 510,000 unique users and 52,164 user accounts.

[8] April 27, 2012.

[9] Corneliu Dobriţoiu, Lieutenant General in Retirement, born on September 18, 1955, in Bucharest. He graduated the "Dimitrie Cantemir" Military High School from Breaza (Prahova County) in 1974, the Academy of Land Forces "Nicolae Balcescu" from Sibiu, in 1977, the Academy of High Military Studies in Bucharest in 1993. Military functions, after his resignation, State Secretary to the Department of Defense Policy (2006-2010). Minister for National Defense between 7 May and 22 December 2012. 
[10] Head of the DIRP Directorate for Information and Public Relations Activities to Achieve Communication Objectives, p.2.

[11] Head of the DIRP on the conduct of information and public relations activities for the fulfillment of the communication objectives, p.4.

[12] DCISM address number RP306 / 08.03.2013.

[13] Convocation Program on the Establishment and Management of the MND Pages in Social Media Platforms, Bucharest, September 20, 2012.

[14] Self-assessment of the status of DIRP in 2012, 19 Feb. 2013.

[15] art. 8, par. $\mathrm{n}$ of the Instructions on Information and Public Relations in the Ministry of National Defense.

[16] art. 83 of the Instructions on Information and Public Relations in the Ministry of National Defense.

[17] art. 82, art. 83 of the Order M76 / 2016 for the approval of the Instructions regarding the information and public relations activity in the Ministry of National Defense.

[18] art. 83 of the Order M76 / 2016 for the approval of the Instructions regarding the information and public relations activity in the Ministry of National Defense.

[19] Analysis of media attitude toward the activity of the military institution in 2017, Analysis of the media attitude towards the activity of the military institution in 2016, Analysis of the media attitude towards the activity of the military institution in 2015, Analysis of the media attitude towards the activity of the military institution in the year 2014, Analysis of media attitude towards the activity of the military institution in 2013.

[20] interview with Mr. Alin Preda, Head of the Online Communication Bureau.

[21] Analysis of the media attitude towards the activity of the military institution in 2016. 